\title{
Ontogenetic structure of Thymus L. (Lamiaceae) coenopopulations in Yakutia
}

\author{
Evgeniya Talovskaya* \\ Central Siberian Botanical Garden SB RAS, Zolotodolinskaya st., 101, Novosibirsk, Russia, 630090
}

\begin{abstract}
Ontogenetic structure of coenopopulations of four model species Thymus extremus, T. indigirkensis, T. brevipetiolatus and $T$. pavlovii widely distributed in Yakutia was studied. It was established that species coenopopulations were normal, most of them incomplete. Dependence of the type of the ontogenetic spectrum of coenopopulations on growth conditions and ontogenesis pattern was revealed in thymes of different biomorphs. The bimodal type of the ontogenetic spectrum (monocentric dwarf subshrub T. extremus) is conditioned by irregular seed regeneration and lack of ripe and old generative stages. Formation of the left-side type of the ontogenetic spectrum is governed by the emergence of vegetative propagation of individuals (unobvious polycentric dwarf subshrub T. brevipetiolatus and dwarf semishrub T. indigirkensis) and substrate features (distinct polycentric dwarf semishrub T. pavlovii).
\end{abstract}

\section{Introduction}

Currently searching for ways of rational nature management has become increasingly important [1,2]. A number of issues along this line are devoted to study of natural reserves of medicinal plant material. Thymus L. species are widely used in both official and common medicine. Mass collection of thymes by local population leads to sharp deterioration of natural population status and, as a consequence, to decrease in natural resources. One of the criteria of assessment of the current status of coenopopulations of medicinal plant species is their ontogenetic structure [3]. Medicinal properties of Thymus species are known since ancient times. They possess disinfecting, analgesic and antiseptic activities. T. extremus Klok., T. indigirkensis Karav., T. brevipetiolatus Čáp and $T$. pavlovii Serg. are widespread in the territory of Yakutia. The main habitats of the species are steppe plant communities on the southern and south-western cobble slopes of river banks and tops of the hills [4]. In literature there are data on the biology of Thymus sibiricus (Serg.) Klokov et Shost. growing in Central Yakutia [5], whereas data on the ontogenetic structure of coenopopulations of this and other species are absent. In this regard, the aim of the work was study of the ontogenetic structure of coenopopulations of model species T. extremus, T. indigirkensis, T. brevipetiolatus, and T. pavlovii in Yakutia.

* Corresponding author: kolegova_e@mail.ru 


\section{Materials and Methods}

Coenopopulations (CP) of four model species T. extremus, T. indigirkensis, $T$. brevipetiolatus, and $T$. pavlovii growing in different ecological-coenotic conditions of Yakutia were studied (Table 1). When studying the ontogenetic structure of CP, standard methods were used [6-8]. The transects $1 \mathrm{~m}$ wide and 5-10 $\mathrm{m}$ long were divided into test plots at $1 \mathrm{~m}^{2}$, a continuous account of individuals at each of the ontogenetic stage was carried out. As a unit of account, a primary shoot, a primary bush and a clump in individuals of seed origin, a partial bush and a system of partial bushes in individuals of vegetative origin were taken into consideration. An ontogenetic spectrum of $\mathrm{CP}$ was defined as a ratio of plants at various ontogenetic stages expressed in a percentage of the total individual number [6]. To characterize CP were used demographic indices of age and effectiveness. The type of a coenopopulation was established by L.A. Zhivotovskiy's "delta-omega" classification [7]. The ecological density of $\mathrm{CP}$ was defined when calculating individual abundance per unit of habitable space [8].

Table 1. Characteristic of habitats of Thymus coenopopulations in Yakutia

\begin{tabular}{|c|c|c|c|}
\hline $\mathrm{CP}$ & Locality of CP & $\begin{array}{c}\text { Community / } \\
\text { dominating species }\end{array}$ & $\begin{array}{c}\text { TPCD/PCD } \\
\% \\
\end{array}$ \\
\hline $\begin{array}{c}1 \\
\text { (T. extremus) }\end{array}$ & $\begin{array}{l}\text { Vicinities of Yakutsk, } \\
\text { gentle slope of the } \\
\text { Lena River bank, } \\
\text { south-eastern } \\
\text { exposure, steepness } \\
10^{0}, \quad \text { meadow- } \\
\text { chernozem sandy- } \\
\text { loam soil }\end{array}$ & $\begin{array}{lr}\text { Herb-sheep's } & \text { fescue } \\
\text { steppe (Festuca lenensis } \\
\text { Drobow, Artemisia } \\
\text { pubescens } \\
\text { Veronica incana Ledeb., } \\
\text { Carex duriuscula C.A. } \\
\text { Mey., } \\
\text { flavescens (Zucc.) Juz.) }\end{array}$ & $80 / 3$ \\
\hline $\begin{array}{c}2 \\
\text { (T. brevipetiolatus) }\end{array}$ & $\begin{array}{l}\text { Kobyansk region, } \\
\text { vicinities of s. } \\
\text { Smorodichny, slope of } \\
\text { southern exposure, } \\
\text { steepness } 5^{0}, \text { loam } \\
\text { with cobble. }\end{array}$ & $\begin{array}{l}\text { Spreading anemone- } \\
\text { sheep's fescue-wildrye } \\
\text { steppe (Festuca lenensis, } \\
\text { Elymus turuchanensis } \\
\text { (Reverd.) Czerep., } \\
\text { Pulsatilla patens (L.) } \\
\text { Mill., Koeleria cristata } \\
\text { (L.) Pers., Veronica } \\
\text { incana) }\end{array}$ & $80 / 1$ \\
\hline $\begin{array}{c}3 \\
\text { (T. indigirkensis) }\end{array}$ & $\begin{array}{l}\text { Kobyansk region, } \\
\text { vicinities of s. Sangar, } \\
\text { slope of southern } \\
\text { exposure of the Lena } \\
\text { River bank, steepness } \\
5^{0} \text { fine grain soil } \\
\text { covered with cobble }\end{array}$ & $\begin{array}{l}\text { Bush encroached by } \\
\text { Spiraea dahurica } \\
\text { (Rupr.) Maxim. and } \\
\text { Rosa acicularis Lindl. } \\
\text { herb bunchgrass steppe } \\
\text { (Agropyron villosum } \\
\text { (L.) Link, Festuca } \\
\text { lenensis, } \\
\text { pediformis C.A. Mey., } \\
\text { Dracocephalum } \\
\text { palmatum Steph. ex } \\
\text { Willd., T. indigirkensis) }\end{array}$ & $60 / 5$ \\
\hline $\begin{array}{c}4 \\
\text { (T. pavlovii) } \\
\end{array}$ & $\begin{array}{lr}\text { Tompo region, } \\
\text { southern exposure of }\end{array}$ & $\begin{array}{l}\text { Grouping of vegetation } \\
\text { (Bromopsis pumpelliana }\end{array}$ & $35 / 5$ \\
\hline
\end{tabular}




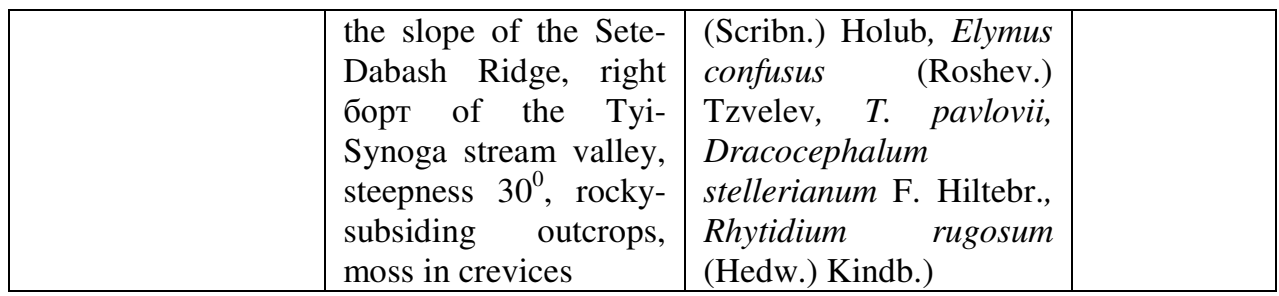

Note: TPCD - total projective cover degree of the herb layer, PCD - projective cover degree of the species.

\section{Results and Discussions}

Study of T. extremus, T. indigirkensis, T. brevipetiolatus and T. pavlovii showed that in Yakutia peculiar morphological mechanisms of adaptation manifesting themselves in the diversity of life forms and biomorph types were formed in the species. In CP $1 \mathrm{~T}$. extremus is a monocentric dwarf semishrub. The phase of a primary bush is prolonged in the individual ontomorphogenesis. Self-maintenance of CP occurs only by seeds. In CP $2 T$. brevipetiolatus and in CP 3 T. indigirkensis are implicitly polycentric dwarf semishrub and dwarf semishrub, respectively. The most prolonged phase in the individual ontomorphogenesis is that of a clump. Self-maintenance of $\mathrm{CP}$ occurs by seeds and vegetatively. IN CP $4 T$. pavlovii is explicitly dwarf semishrub. An adult individual also represents a clump. Self-maintenance of CP occurs vegetatively. Studied CPs of model species are normal, mostly incomplete (subsenile individuals are absent) (Table 2).

Table 2. Distribution of Thymus species individuals throughout the ontogenetic groups

\begin{tabular}{|c|c|c|c|c|c|c|c|c|c|c|c|c|}
\hline $\mathrm{CP}$ & \multicolumn{8}{|c|}{ Ontogenetic groups, \% } & \multirow{2}{*}{$\mathrm{D}_{\text {ecol. }}$} & $\omega$ & \multirow{2}{*}{$\Delta$} & CP type \\
\cline { 2 - 13 } & $\mathrm{j}$ & $\mathrm{im}$ & $\mathrm{V}$ & $\mathrm{g} 1$ & $\mathrm{~g} 2$ & $\mathrm{~g} 3$ & $\mathrm{ss}$ & $\mathrm{s}$ & & & & \\
\hline 1 & 12.2 & 17.1 & 7.3 & 17.7 & 15.2 & 9.8 & 20.1 & 0.6 & 23.4 & 0.55 & 0.42 & transitional \\
\hline 2 & 0.4 & 6.3 & 15.7 & 33.2 & 16.2 & 19.7 & 8.5 & 0 & 40.0 & 0.70 & 0.41 & transitional \\
\hline 3 & 3.8 & 5.0 & 20.0 & 38.1 & 13.2 & 15.0 & 4.9 & 0 & 74.3 & 0.67 & 0.35 & transitional \\
\hline 4 & 13.2 & 36.8 & 17.6 & 19.1 & 5.9 & 1.5 & 5.9 & 0 & 8.5 & 0.39 & 0.19 & Young \\
\hline
\end{tabular}

Note. Ontogenetic groups: $\mathrm{j}$ - juvenile; im - immature; $\mathrm{v}$ - virginal; $\mathrm{g} 1$ - young generative; $\mathrm{g} 2$ - ripe generative; $\mathrm{g} 3$ - old generative; ss -subsenile; $\mathrm{s}$ - senile; $\mathrm{D}_{\mathrm{ecol}}$ - ecological density (individual $/ \mathrm{m}^{2}$ ); $\omega$ -effectiveness index; $\Delta$ - age index; type of coenopopulations according to L.A. Zhivotovskiy's classification (2001).

The ontogentic spectrum of CP 1 T. extremus is bimodal. An absolute maximum is in the right-side part of the spectrum on subsenile individuals. Two local maxima are distinguished on immature and young generative individuals in the left-side part of the spectrum. Multiple top of the spectrum is conditioned by different factors. On the one hand, irregular seed regeneration encourages accumulation of different groups of regrowth. On the other hand, accumulation of subsenile individuals is linked with features of T. extremus development in forb-sheep's fescue steppe community with a lack of water supply and high sodding. So young individuals pass to the subsenile stage omitting ripe and old generative ones. In this regard, the group of ripe generative individuals in CP 1 does not prevail. According to "delta-omega" classification the $\mathrm{CP}$ is transitional.

The ontogenetic spectra of CP 2-4 are left-side, with the maximum on young generative (CPs 2 and 3) and immature individuals (CP 4). Formation of the left-side ontogenetic spectrum in CPs 2 and 3 in T. brevipetiolatus and T. indigirkensis is similar. Both CPs occur in the steppe communities on hill slopes. Vegetative spreading and 
propagation are typical of species individuals in these conditions. Vegetative propagation occurs at the ripe generative stage. Ramets rejuvenated up to the young generative stage and sometimes in $T$. indigirkensis up to the virginal one annually separate from the maternal individual. This, as well as seed regeneration promote increase in young generative individual group and formation of the peak in the left part of the spectrum. Ecological density of CP of implicitly polycentric thyme species is high and reaches in $T$. indigirkensis 74,3 individual $/ \mathrm{m}^{2}$. CP self-maintenance is equally by seed and vegetative ways. Genet-ramet ratio is practically the same: in T. brevipetiolatus $\mathrm{CP}$ it amounts to 1:1,4, in T. indigirkensis CP - 1:1,2. According to "delta-omega" classification CPs 2 and 3 are transitional to ripe ones.

In T. pavlovii a rise in the left part of the spectrum falls on the group of immature individuals. The species habitat is characterized by specific features of the substrate. Individuals develop on the moss cover in the crevices of rocky outcrops. Favourable conditions for seed germination are formed here. However, only a small quantity of individuals passes to virginal stage in the future. This is linked with an adverse effect of moss in individual life at the later ontogenetic stages (conservative of permafrost, assists in preservation of soil low temperatures, leads to swamping). The same thing is also noted by J. L. Gornal et al. [9]. Duration of the ontogenesis of T. pavlovii genets does not exceed 8 years. At the ripe generative stage primary individual structures decay, and a plant breaks up completely into even-aged partial formations. CP self-maintenance is mainly due to vegetative regeneration of ripe generative individuals. Genet-ramet ratio in $\mathrm{CP}$ is 1:3,5. According to "delta-omega" classification CP 4 is young.

Thus, the study of the coenopopulations of model Thymus species in various ecological-coenotic conditions of Yakutia shows that all of them are normal, most of them are incomplete (individuals at the senile ontogenetic stages are absent). Dependence of the ontogenetic spectrum type on growth conditions and ontogenesis pattern was revealed in species of various biomorphs. Similar dependence was also revealed by some researchers when studying plant population structure in certain regions [3, 10 and others.]. A bimodal type of the ontogenetic spectrum in the monocentric dwarf semishrub T. extremus is governed by irregular seed regeneration and omitting ripe and old generative stages. Formation of the left-side ontogenetic spectrum of CP in implicitly polycentric semishrub $T$. brevipetiolatus and dwarf semishrub $T$. indigirkensis is conditioned by emergence of individual vegetative propagation, ramet rejuvenation (up to the young generative stage), combined way of $\mathrm{CP}$ self-maintenance. Accumulation of regrowth and formation of the left-side spectrum in explicitly polycentric dwarf semishrub $T$. pavlovii are to a greater extent due to peculiarities of moss substrate.

The work was carried out with the financial support of the grant of RFBR within the framework of project № 18-04-00621 and State Assignment of Central Siberian Botanical Garden SB RAS № AAAA-A17-117012610053-9

\section{References}

1. O.V. Smirnova, N.A. Toroova, Advances in current biology 136, 199-211 (2016)

2. S.-L. Chen, H. Yu, H.-M. Luo, Q. Wu, C.-F. Li, A. Steinmetz, Chin. Med. 11, 37-44 (2016)

3. O.V. Simonova, Principles and methods of biodiversity conservation (MarSU, Yoshkar-Ola, 2010) (In Russian)

4. V.M. Vasjukov, Bot. J. 101, 1240-1253 (2016)

5. P.V. Egorova, Bul. of KrasGAU 7, 65-69 (2014) 
6. O.V. Smirnova, L. B. Zaugol'nova and etc, Cenopopulation of plants. 217 (1976) (In Russian)

7. L.A. Zhivotovsky, Rus. J. of Ecol. 1, 3-7 (2001).

8. Y. Odum, Ecology (Moskow, 1986)

9. J.L. Gornal, S.J. Woodin, I. S. Lonsdottir, R. Van der Wal, Oecologia 166, 769-782 (2011)

10. L.C. Bernacci, Acta Botanica Brasilica 22, 119-130 (2008) 